https://doi.org/10.15407/mineraljournal.42.01.076

UDC 658.56: 622.8.012.2:519.71

V.O. Pryvalov, DrSc (Geology), Prof., Leading Researcher

M.P. Semenenko Institute of Geochemistry, Mineralogy

and Ore Formation of the NAS of Ukraine

34, Acad. Palladin Ave., Kyiv, Ukraine, 03142

E-mail: vitaliy.privalov@gmail.com

http:/ / orcid.org/0000-0002-1429-6960

O.A. Panova, PhD (Geology \& Mineralogy), Senior Research Fellow,

Leading Researcher. M.P. Semenenko Institute of Geochemistry, Mineralogy

and Ore Formation of the NAS of Ukraine

34, Acad. Palladin Ave., Kyiv, Ukraine, 03142

E-mail: olena.panova@gmail.com

http:/ / orcid.org/0000-0002-3813-5125

A.V. Pryvalov, BSc (Environmental Geosciences), MSc student

Czech University of Life Sciences

Kamýcká 129, 16500 Praha-Suchdol

E-mail: andriy.privalov@gmail.com

https:/ / orcid.org/0000-0002-3045-7111

\title{
GEOLOGY IN ENVIRONMENTAL MANAGEMENT ISSUES OF THE DONBAS WITHIN THE CONTEXT OF ITS FORTHCOMING RESTORATION
}

The Donets Basin or Donbas frames one of the major late Palaeozoic coal-bearing basins in the world. Geologically, the basin stands out by its thick sedimentary column containing prolific coal-bearing measures. Within the domain of the Donbas Foldbelt, it is characterized by prominent inversion-folding patterns controlled by principal displacement zone (PDZ). Historically, the Donbas region has served as a heartland of Ukrainian industry including coal and mercury mining, multiple metallurgical and chemical processing plants. Because of tremendous amount of organic matter became thermally mature the basin hosts unconventional gas plays including "shale gas" and coal-bed methane resources, which may be served a resource base to cease the Ukrainian dependence on gas imports from the Russian Federation through unconventional gas developments. Nowadays, this geological and economic-geographical region suffers from military hostilities, which may have unpredictable consequences and threaten the security of adjoining regions. The aim of this publication is to ascertain the threat of a dramatically deadly combination of historically persistent man-made environmental damage and armed conflict which affected surface terrain and underground environment, urban and infrastructural facilities, lands and agricultural development within the Donbas region (Eastern Ukraine). We used the extensive dispersed long and short-term observation data collected and acquired in the Donets Basin in order to describe, classify and retrieve the most pressing environmental concerns, as well to delineate future goals for its forthcoming recovery. A scope of environmental problems is given with special stress on interval from 2014 up to the present time including delineation of risks related with specific geostructural position of "Cleavage" underground nuclear blast site and induced seismic activity reported within Khanzhonkovo site (Obyedinenyi settlement) of Makiivka region in 2019. Methods of detection and prevention are described and the potential size of the problem is assessed. The scopes of remedial measures that may be taken are discussed.

Keywords: Donbas, geo-hazardous sites, military conflict, environmental impacts, "Cleavage" site of underground nuclear blast, induced seismicity, land contamination.

Цитування: Pryvalov V.Ō., Panova O.A., Pryvalov A.V. Geology in Environmental Mänagement Issues of the Donbas Within the Context of Its Forthcoming Restoration. Mineral. Journ. (Ukraine), 42, No. 1, Kyiv, UA, pp. 76-85. https:// doi.org/10.15407/mineraljournal.42.01.076 
Introduction. The Donets Basin (Donbas) is one of the major in the world Carboniferous coal fields with multiple coal seams. That is why, historically, the Donbas region has served as a heartland of Ukrainian industry including underground coal and mercury mining, multiple metallurgical and chemical processing sites. Because of the anthropogenic activity, the wild steppe-forest nature of the Donets Basin was transformed into an industrially polluted region of undesirable outcome of harmful by-products, wastes and emission of toxic chemicals into the environment. The basin hosts prolific unconventional gas plays including significant "shale gas" and coal-bed methane resources. Very promising in terms of attractive exploration and investment potential the Yuzivska site in the Donbas was believed to contain the European scale resource play of environmentally-friendly natural thermogenic methane $[3,12,15]$. Unfortunately, because of military hostilities multinational and Ukrainian geologically oriented research entities stopped their exploration activities across the Donbas. Right now, this geological and economic-geographical region suffers from almost 6 -yrs story of military conflict, which may have unpredictable consequences.

Geological background of the Donets coal Basin. The Donets coal Basin (Donbas) covers an area of $60.000 \mathrm{~km}^{2}$ and it is located immediately southeast of the Dnieper-Donets Basin, one of the most mature oil and gas provinces of Ukraine. Geologically, it forms a most anomalous segment (Fig. 1) of continuous the Pripyat-Dnieper-Donets-Karpinsky (PDDK) rift within southern-eastern margin of the East European Craton (EEC) [1, 5, 9 and 19]. The Donets Basin stands out by its up to $24 \mathrm{~km}$ sedimentary column with prominent inversion.

The PDDK rift was formed during Late Devonian break-up of the Sarmatia protoshield. At the area of the Donets Basin, Late Archean terrains within the Voronezh Massif and the Priazov Block of the Ukrainian Shield were reworked in the Early Proterozoic orogenesis [9]. This has been resulted in formation of a number of subsequently inverted and eroded trough-type elongated basins with predominant NNW striking grain. In fact, these are not randomly distributed. Many of them cluster along a discrete NNW-trending corridor bracketed by two transcrustal Mariupol-Kursk (MK) and Lipetsk-Konstantinovsk (LK) lineaments [5, 12 and 15]. The corridor served as particularly weak zone within the Craton. It plunges beneath the Donbas segment of the PDDK rift and appears to propagate beyond the southern margin of the
EEC into orogenic terrains of the Trans-Caucasian transverse uplift, possibly because it acted repeatedly as a stress concentrator during collisional tectonic events.

In 3-D view, the Donbas is a deformed prismatoidal block located on the intersection of the NNW striking Early Proterozoic weak zone within the Sarmatian segment of the EEC and the Late Devonian PDDK rift (Fig. 1, $a$ ).

The structure of the Donbas Fold-and-Thrust Belt, which is the inverted part of the Donbas Basin, is dominated by WNW-ESE trending linear folds in the central part of the basin (Fig. 1, b). Tectonic patterns within the Main anticline can be interpreted as "flower structures" bearing the scars of repeated strike-slip deformations (Fig. 1, $d$ ). Major thrusts occur along the northern margin of the basin in the limits of a zone of the Northern SSW-dipping deep fault, which is rooted in the Moho (Fig. 1, c). The southern margin of the basin is represented by a set of adjoining horst - graben structures within a zone of the Southern NNEdipping deep fault. Minor folds, reversed faults with significant and even dominating strike-slip displacement components, rotated fault blocks occur between zones of marginal deep faults and central zones of linear folds (Fig. 1,c).

The important tectonic element of intrabasinal architecture is the WNW-ESE trending principal displacement zone (PDZ) [11] consisting of a set of dextrally en-echelon arranged deep basement faults with overstepping jogs of a different scale or pull-aparts of megascale $P A$ and mesoscale $M A$ (Fig. 2).

Some of them, jogs of megascale (excluding the most inverted Nagolniy Ridge jog PA4) coincide with depicted after seismic records depressions in the crystalline basement with depth in range of $-20 \ldots-24 \mathrm{~km}$. The jog $P A 4$ is located within restraining stepover structure of the Nagolniy Ridge on the junction of Central and Persiyanovsky faults, where the crystalline basement lies at a depth of $-14 \ldots-16 \mathrm{~km}$. During post-rift stage strike-slip pulses within the principal displacement zone affected local depositional environments in the vicinity of pull-aparts, which have been served as local dilatational jogs with marks of syntectonic sedimentation (during dextral reactivation of the PDZ) or contractional push-up structures (during sinistral reactivation of the $\mathrm{PDZ}$ ).

The most prominent deep fault within the PDZ is expressed in Palaeozoic strata as the Main Anticline, which is the largest and most pervasive fold 


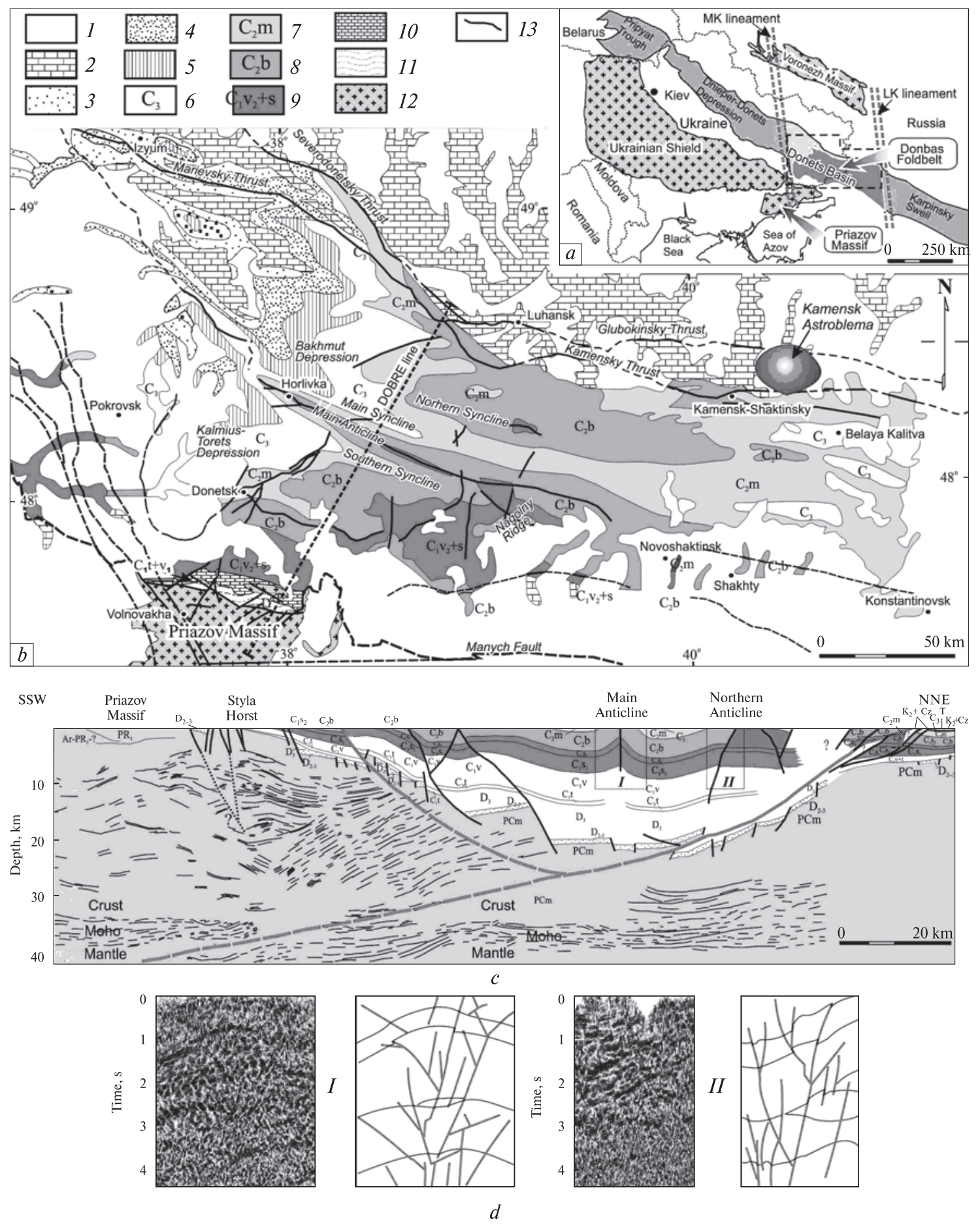

Fig. 1. Location of the study area (a); geological sketch map of the Donets Basin $(b)$; geological cross-section along DOBRE seismic profile $(c)[18,19]$; flower type structures depicted from fragment of DOBRE reflection records $(d)$. $1-$ Cenozoic, 2 - Upper Cretaceous, 3 - Jurassic, 4 - Triassic, 5 - Permian, 6 - Upper Carboniferous, 7 - Middle Carboniferous (Moscovian), 8- Middle Carboniferous (Bashkirian), 9 - Lower Carboniferous (Upper Viséan - Serpukhovian), 10 - Lower Carboniferous (Tournasian - Lower Viséan), 11 - Devonian, 12 - Precambrian, 13 - faults

with steeply dipping limbs, complicated by faults developed at its hinge, in which strike-slip movements have been recognised. The documentation of kinematic indicators within faults under deep structure of the PDZ attests to an existence of sign- variable dextral and sinistral strike-slip displacements as in pre-folding (before tilting) and following stages of the structure development.

Major post-rift subsidence occurred during the Carboniferous and was under a control of interplay ISSN 2519-2396. Mineral. Journ. (Ukraine). 2020. 42, No 1 

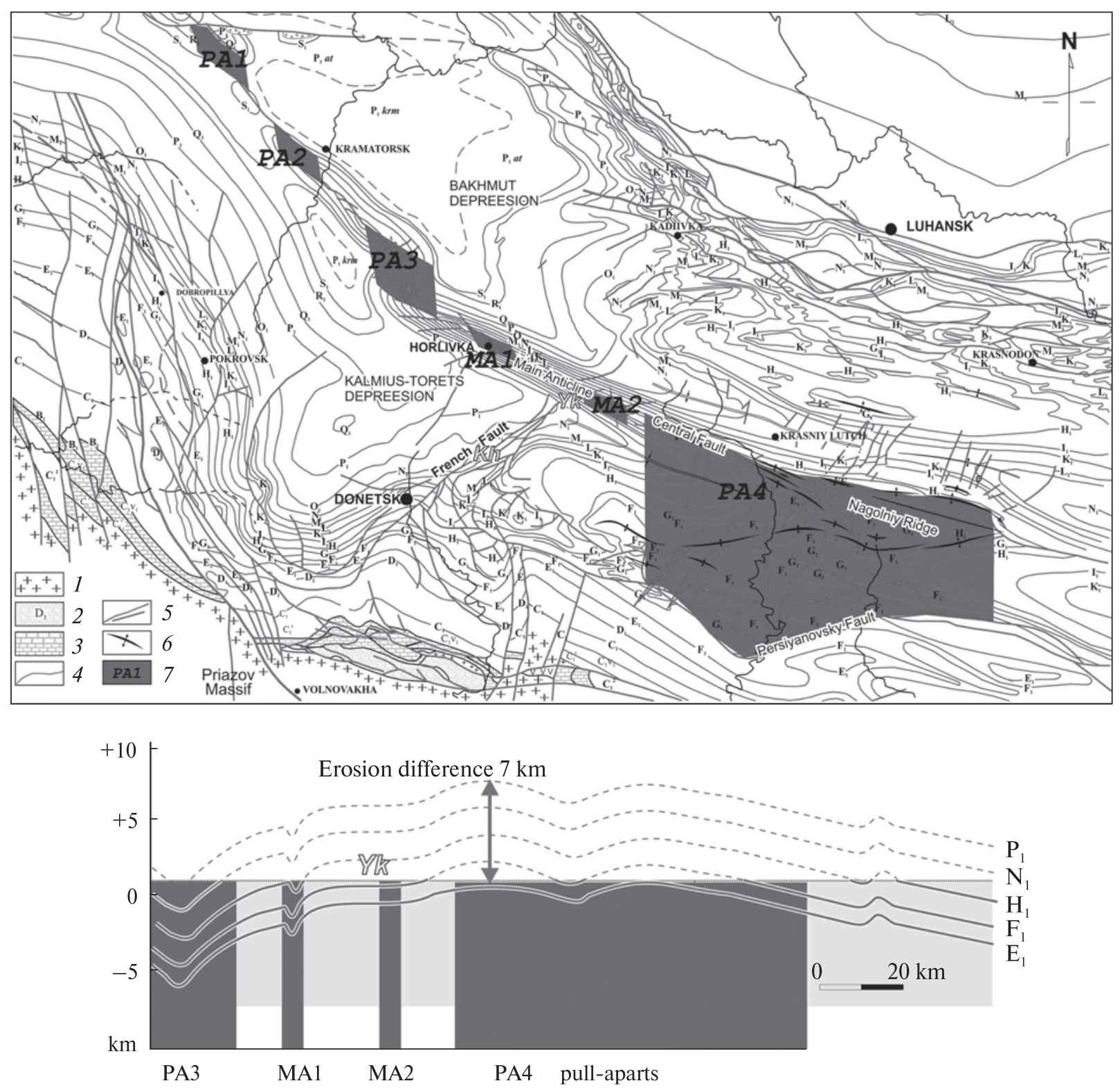

Fig. 2. Position of the principal displacement zone (PDZ) on geological map of pre-Mesozoic sediments of the Donbas and geological section along the axis of the Main Anticline with location of pull-aparts [11, 14]. $1-$ Precambrian, $2-$ Devonian, 3 - carbonate suite A (Tournasian - Lower Viséan), 4 -limestone bands of post-Upper Viséan paralic succession and Early Permian succession; 5 - faults, 6 - anticlines, 7 - pull-apart jogs. $2-$ Yk - Yunkom site of "Cleavage" nuclear explosion experiment; $\mathrm{Kh}$ - Khanzhonkovo site (Obyedinenyi settlement) of induced seismic activity (2019 - present time)

of prevailing subsidence during local extension and short-time uplift pulses during local compression within stepover jogs. This conclusion allows giving a logical explanation to the phenomenon of lateral translation of the main depocentral axis of the Carboniferous stratigraphic units to south from the Main Anticline, i. e. along line connecting centres of jogs $P A$.

Because of the enormous coal resource base and the economic challenges associated with its largescale exploitation, the Donets Basin has been a major focus of coal exploration for more than two centuries. Thick coal-bearing measures formed during the post-rift stage of the basin. The postEarly Viséan Carboniferous fill hosts about 330 coal seams and layers.

The coal-bearing strata consist of cyclic successions of marine, continental and transitional facies. An elementary sequence ( 20 to $40 \mathrm{~m}$ thick) is composed of fluvial sandstone, coal seam, marine limestone or mudstone, and deltaic claystone or siltstone [6]. With the exception of the carbonate 


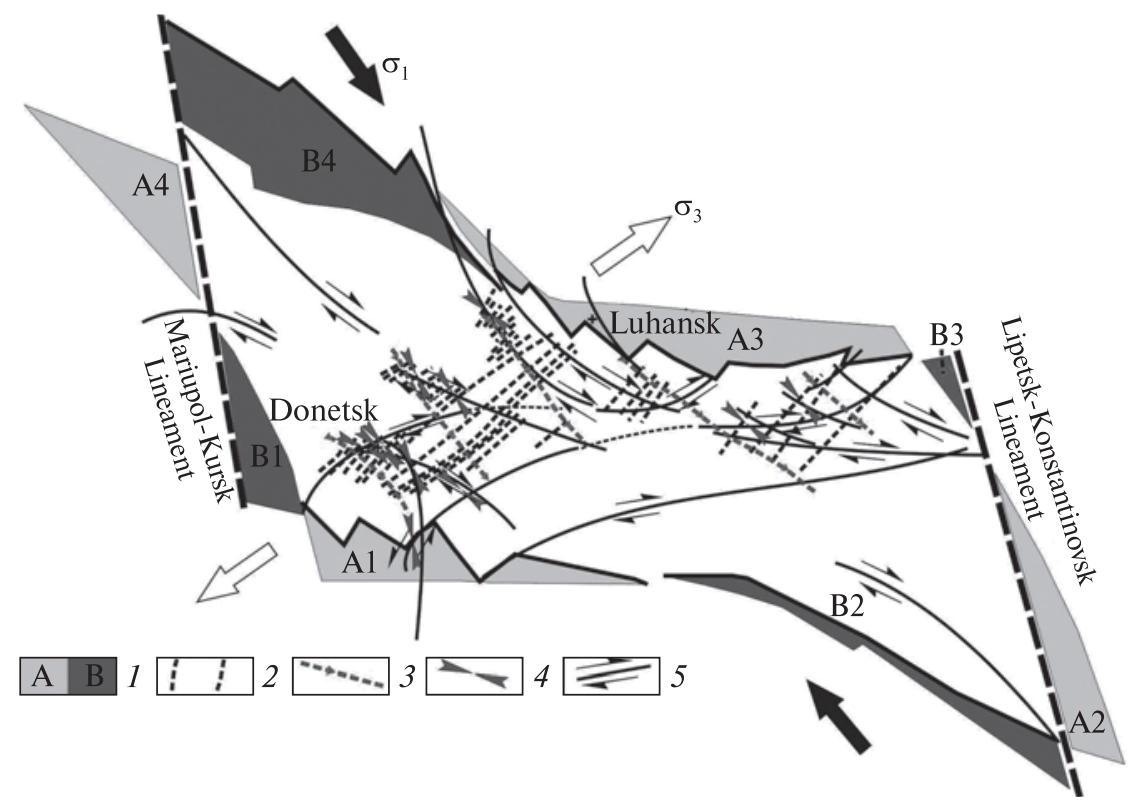

Fig. 3. Mechanism of forming linear and subconcentric strike-slip zones and induced zones of geodynamic activity in coal mines in sedimentary cover of the Donbas [11]. $1-$ sectors of local extension (A) and compression (B); $2-$ zones of recent geodynamic activity (rock-gas and coal outbursts); 3 - trajectories of horizontal compression $\sigma_{1}$ of modern stress field; 4 - trend of compression $\sigma_{1}$ of Apine stress field; 5 - subconcentric and linear strike-slip fault zones due to clock-wise torsion of the Donbas megablock

suite A of Tournaisian and Early Viséan age, coal seams and intercalations of coal are present throughout the Carboniferous successions. However, lower Serpukhovian and Moscovian successions are especially rich in coal [9]. Total coal thickness in Carboniferous formations is about $60 \mathrm{~m}$. Donbas coals are generally rich in vitrinite, with average contents of $81 \%$. Inertinite and liptinite macerals have mean contents of 12 and $7 \%$, respectively. Some Serpukhovian samples exhibit higher inertinite (up to 58\%) and liptinite (26\%) percentages [17].

The numerical basin modelling of the Ukrainian part of the Donbas based on results $[1,2,4]$ indicates that Carboniferous coals and dispersed organic matter in coal-bearing measures are thermally mature in the deep basin and have generated large volumes of gaseous hydrocarbons in the South and the Main synclines, where Lower Permian seal rocks are preserved [2]. It was inferred that the higher amounts of trapped methane are located at $4 \mathrm{~km}$ depth within the junction of the KalmiusTorets and the Bakhmut Depressions (the Yuzivska site) with strong structural control by non-inverted pull-apart jogs [14]. During multiple CimmerianAlpine dextral reactivations of the PDZ these jogs had been served as dilatational domains and the most favourable places for localizing of abnormal heat flows and hot fluids transport responsible for thermogenic gas generation with further trapping in high-permeability and fractured secondary reservoirs [10]. Gas from deep over pressured compartment and low-permeability levels may have escaped via several major fault and fracture zones or through outcrops along the margins of the basin. It has been concluded $[12,15]$ that two inversion events have impacted negatively to methane preservation potential in brittle coal seams. On the contrary, intervals of deep-seated plastic gas-rich argillaceous and tight sandy-aleurolitic rocks with low matrix permeability and low open porosity could keep considerable volumes of methane, even after inversion events.

Despite the Variscan fold belt structural grain the Donbas has been affected considerably by Alpine and neotectonic structural deformation events $[4,13]$ resulted in induced coal-and-gas outburst activity of a seismic nature $[9,11]$. The Fig. 3 depicts the latest Alpine dextral subconcentric strike-slip fault zones reactivations within the Donbas associated with regime of clock-wised torsion of the Donbas megablock. The regional spatial location of geodynamic (rock-gas and coal outbursts) zones of can be explained by: i) developing of subconcentrric dextral shear zones 2) by recent NW-SE compression vector oriented perpendicular to trend of these zones.

The most pressing environmental concerns of the Donbas and possible solutions within the context of its forthcoming future recovery. Once recognized as the industrial heartland, the Donbas was transformed into an industrially polluted region. The environmental risks within this region have increased in recent years dramatically because of cruel armed conflict from many standpoints. On the one hand, geohazards that result directly from armed conflict had made a considerable impact on people's living standards.

ISSN 2519-2396. Mineral. Journ. (Ukraine). 2020. 42, No 1 

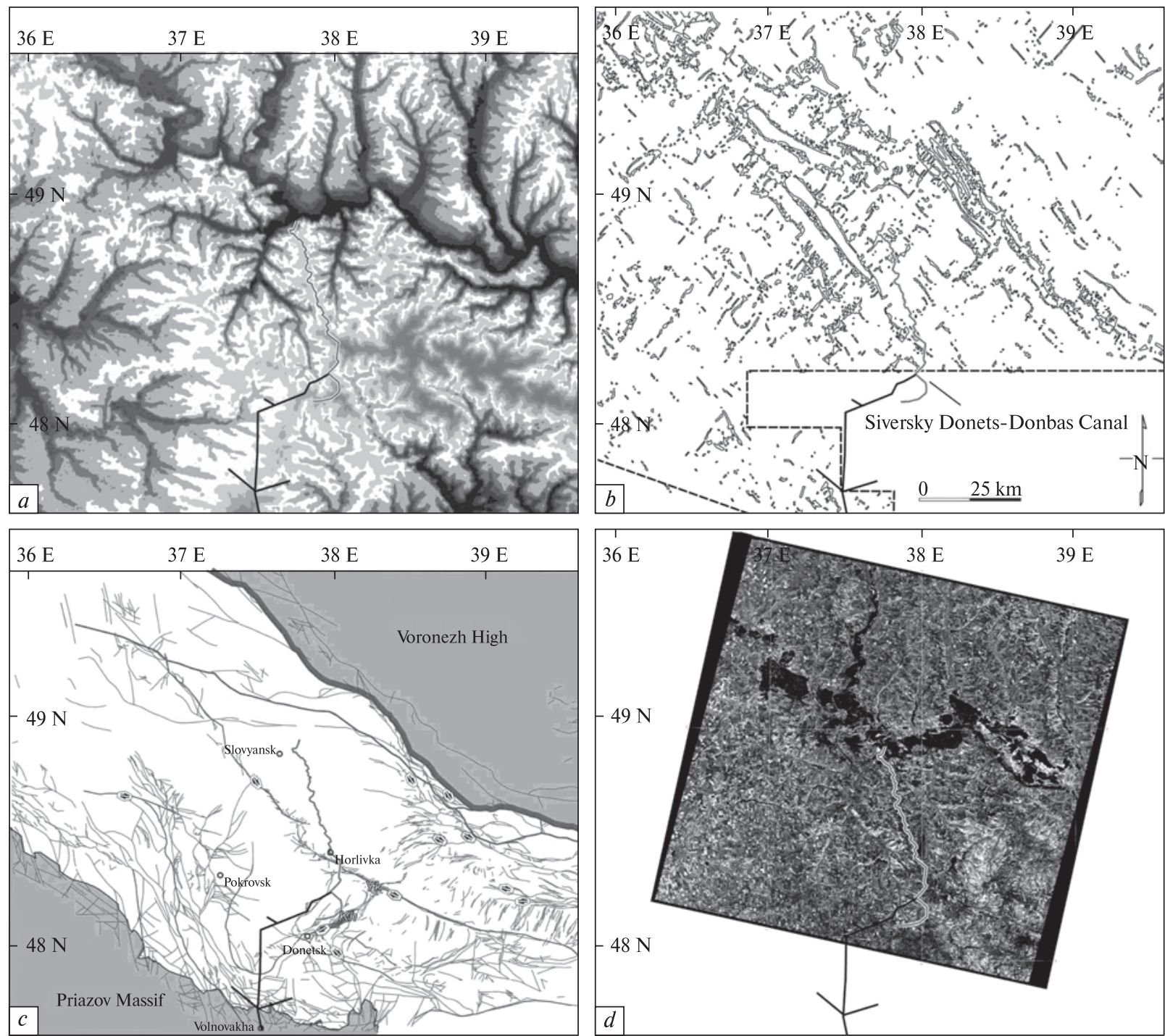

Fig. 4. The Siversky Donets-Donbas Canal on: $(a)$ terrain digital elevation model; $(b)$ deep-seated structures induced from gravimetric anomalies; $(c)$ tectonic map with indication of dextral strike-slip zones [10, 12]; (d) Land Sat satellite image. Yk - Yunkom site of "Cleavage" nuclear explosion experiment; Kh - Khanzhonkovo site of induced seismic activity (2019 - present time)

On the other hand, the cascading effects from armed conflict in the Donbas can have unforeseen consequences.

In a positive feedback loop, warfare triggers a feedback to amplify the effects of geo-environmental damages caused by the pre-war human's impact on natural ecosystems. Overall, military clashes in the Donbas launched a domino effect for degradation pulses of the environment ranging from neglecting geologic and geotechnical ha-zards' monitoring to new wave of water contamination, land degradation, emitting into the environment toxic metals and mineral salts from munitions and bomb shelling fragments and related by-products.
We used the extensive dispersed long and shortterm observation data collected and acquired in the Donets Basin in order to describe, classify and retrieve the most pressing environmental concerns, as well to delineate future goals for its forthcoming recovery.

1. Water management problem. Our lives and livelihoods depend on a clean water environment. While water contributes undoubtedly to economic development, and the industrial revolution in the Donbas triggered the inevitable processes of degradation of ecosystems including the depletion of renewable water resources sources. The safety and accessibility of potable quality drinking water are among major challenges throughout the region. 


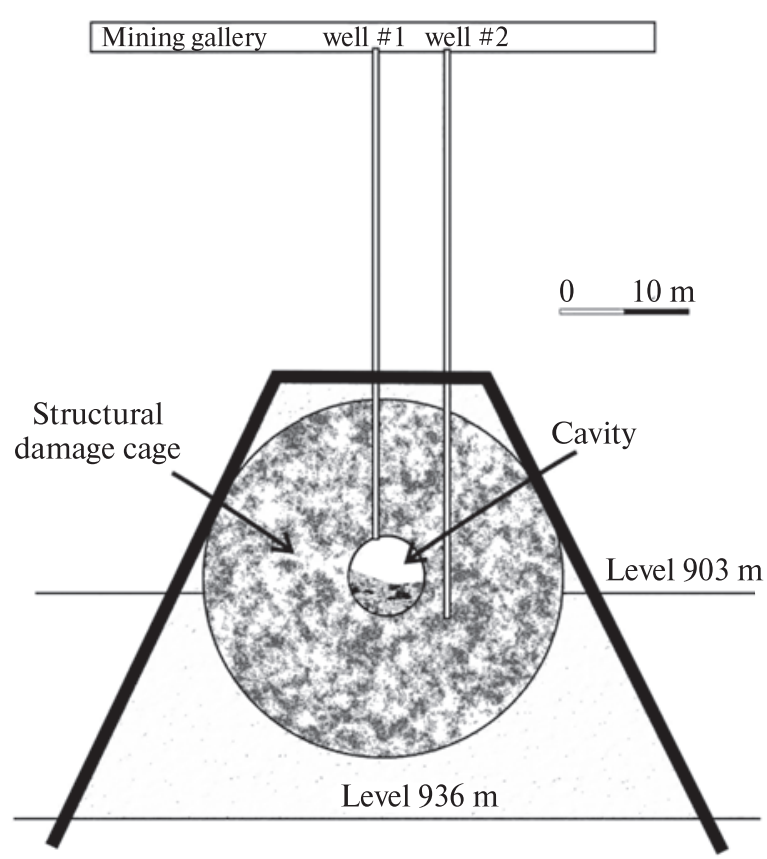

Fig. 5. Inspection wells (\#1 and \#2) for the "Cleavage" experiment depicting dimensions of explosion cavity surrounded by vitrified capsule and structural damage cage in sandstone layer

Since 1958 the Siversky Donets-Donbas Canal serves as the arterial main water source supply for of the region. Geologically, the trace of the canal is going through a set of tectonically active releasing sites and tension fractures (Fig. 4) that are responsible for multiple seepage-and-leakage incidents, geotechnical canal instability emergencies and broadly speaking maintenance problems.

Currently, because the human's impact on natural ecosystems (in relation with water contamination, land degradation, emitting into the environment toxic metals and mineral salts from munitions and bomb shelling fragments and combustion by-products related with military hostilities) the harmfully polluted water from the canal is responsible for dramatic decreasing of health safety. Meanwhile, the region and, more specifically, its part located within the Priazov Massif are rich in groundwater reservoirs. For example, only single the Yalynsky groundwater field at the Volnovakha district has about 8 to 10 years of proven reserves for consumption in Mariupol and Volnovakha regions.

We propose the reasonable solutions:

(1) The Siversky Donets-Donbas Canal's site investigations with particular emphasis on airborne hyperspectral surveys and ground geophysical methods;

(2) Water consumption in restored Donbas should be gradually switched on ground water resource development, which can be the only one safe source on fresh water.

2. Coal mine flooding and related problems. Traditionally huge territories of the Donbas after mining by the longwall method were involved in downward ground movements. Many urban environments here are located in tectonically stressed regions wherein dense network of tectonic fractures together with mining subsidence produce mininginduced fault reactivation.

This hazardous phenomenon of fault scarping is associated both with active mining and with the post-mining period. Faults may also increase the permeability of a coal-bearing massive and provide sites for local discharging ground or even mine waters, and breathing of deadly explosive mine gases. Stopping pumping out underground mine waters after closing mines gives a risk of new trend of appearing upward surface movements [20] on the background of previously occurred mining subsidence. This process facilitates the strength loss in communication infrastructure including pipelines ruptures, breakdowns of sewage and water supply systems. Operational disruptions caused by these incidents have already been widely reported.

We propose to use a remote-sensing approach, e.g. satellite imagery combined with laser scanning (LIDAR) systems in the investigation of hazardous sites to address these issues for recording morphological changes of ground surface movements, detecting and predicting scarp traces incidents and the roles played by mine-water rising levels of and the methane breathing effects following coalfield abandonment.

3. The problem of radioactive decay products. The most famous intrusion into the environmentally concerned mind comes from the "Cleavage" deadend experiment launched by the Skochinsky Institute of Mining located in Lyubertsy, Russia.

A $300 \mathrm{~kg}$ (TNT equivalent) nuclear device was emplaced and activated at a depth of 903 meters (September 16, 1979) in a sandstone layer on the southern limb of the Main anticline within the "Yunkom" mine (Yenakiieve town) with the ultimate aim to discharge tectonic stresses responsible for coal-and-gas outbursts.

Radioactive material produced by a nuclear explosion remains underground due to the combined action of the strength and the sealing behaviour of compressed rock around the cavity, lithostatic pressure of the rock, and the stemming of the emp-

ISSN 2519-2396. Mineral. Journ. (Ukraine). 2020. 42, No 1 
lacement shaft. The inclined shaft was sealed with concrete to prevent releasing gaseous radionuclides to the surface or into mine galleries. The paricular location of "peaceful" nuclear blast in a sandstone layer was chosen to assure creating vitrified capsule to minimize the transport of radioactivity from the explosion site. In theory, the stress outside of highly fractured damage cage heals any fractures that may have begun and prevents new fractures from forming.

This isolation pattern together with melted siliceous (sandstone-derived) capsule helps to contain non-condensable gases such as carbon dioxide and hydrogen including its radioactive isotope tritium. Tritium is a radioactive form of hydrogen generated as a by-product of energy production in nuclear detonations including "Cleavage" experiment.

There is a plenty of evidences supporting the conclusion that tritium is a non-threshold chemical carcinogen. In fact, tritium exposure combines with oxygen a form of deadly "drinking water" molecules with extreme mutagenic risk potential.

As many strike-slip faults are present, major tectonic discontinuities also can have an effect of long-termimpactsonwater-flooding environments, wherein the fluid flow and dissolution paths are controlled by stress-strain state of the rock mass [13].

More specifically, within the Yunkom site, a set of meso- and microscale pull-aparts (e. g. jogs $M A 1, M A 2)$ extend throughout the principal displacement zone (PDZ) and form loci for convective hydrodynamic fluctuations wherein local dilation jogs act as vertical pipe-like conduits for enhanced fluid flow. During fault re-activation caused by mining subsidence or even seismically induced stress discharge, pore volume is rapidly created by dilation resulting in a change in pore fluid pressure which may enable fast migration of radioactive pollutant.

Such a peculiarity in geo-structural environment of the nuclear blast site in close vicinity to the pullapart $M A 2$ can greatly increase risks of water contamination by reactive chemicalsand radioactive fission products including tritium. Moreover, stopping dewatering pumps and related flooding of underground excavations and surrounding rocks within the Yunkom site (as, in fact, it was happened in many locations within temporarily uncontrolled Donbas Basin's territories of Ukraine) has already triggered a slightly-controlled phenomenon of fluid-induced seismicity.

Actually, there are many observations and comments depicting a pattern of widely occurred within the Khanzhonkovo site (Obyedinenyi settlement) of Makiivka region (since 2019 up to present time) seismic small-magnitude quakes and tremors, which have been likely provoked by stopping mine water pumping in close vicinity to the French Fault. Most of the mines here are (or were) operated within fault-bounded domains. Strike-slip component of deformation is recognized across the entire basin even for segments of regional thrusts and reversed faults [15].

Morphologically, the French Fault itself can be interpreted as regional tectonic discontinuity (combination of reversed and strike-slip fault) with displacement in excess of $300 \mathrm{~m}$ and huge damage zone normally impeding mining and forming the natural boundary of a number of mines. Here, at the Khanzhonkovo site, the French Fault is dextrally reactivated within the strike-slip zone $[15,16]$ of lazy Z-shape geometry trending from Donetsk towards the Main anticline (very close to the Yunkom mine) and further to the northern edge of the basin.

There is no doubt that restoration of the water table provides an excellent option for the injection of the fluid into the fault damage zone. This facilitates the lubrication of fractures, a decrease of friction coefficient with further triggering fault reactivation and earthquake nucleation.

Such scenario possesses high-risk potential to failure vitrified capsule of former nuclear explosion. The post-shot drilling inspection of the mine site in 1991 had revealed a structural damage pattern depicting complex rupture processes within the immediate vicinity of the explosion (Fig. 5).

Therefore, to avoid this negative impact we propose a stepwise approach for implementing a repository program where successful monitoring of the radioactive sites must be combined with retaining the option to retrieve the emplaced radioactive sources, if necessary.

4. The problem of soil and land contamination by toxic metals. The more than 200 years' intensive mining and other industrial activity in the Donbas region have resulted in the accumulation of a few thousands of environmentally risky sites that contain toxic substances, ranging from heavy metals to industrially derived chemical pollutants.

Large amounts of toxic elements in atmosphere and soils originate from the extensive use, burning and further industrial coking coal for steel production.

In addition, residual problems left by have ensued not only from relatively well-recognized coal 
extraction but also from mercury working. Donets Basin hosts the second in the Europe (after Almaden, Spain) Nikitovka $\mathrm{Hg}-\mathrm{Sb}$ ore field. Geologically, the Basin stands on the deep-seated shear zone with a set of releasing jogs or pull-aparts [11], providing a strong basis for mercury influx throughout the entire Carboniferous succession.

Mercury has been extracted here on an industrial scale by the mine and multiple open-pits [7]. Mercury itself, and in combination with other highly mobile toxic metals ( $\mathrm{As}, \mathrm{Sb}, \mathrm{Pb}$ ), tend to accumulate in living organisms creating many harmful compounds, both inorganic and organic. These defunct sites of mercury mining and processing together with a dozen hundreds of cone-shaped mine-waste heaps are amongst of the biggest sources of soil contamination by metals such as mercury.

Donetsk Oblast' has one of the European most fertile black soils assets. Apart from chronic soil contamination problems of a highly industrialized region, war-related degradation of the agricultural land environment will give rise to specific problems stem from deterioration of food quality management, mitigation of sanitary norms for food products and consumption/exporting of potentially harmful agricultural raw and processed products. Accessibility of good-quality food on a sustainable basis has become a global life-threatening problem.

For the past two decades, biochar and nano zero-valent iron (nZVI) have been investigated as new and successful tools for the treatment of contaminated water and soils [7, 21]. Nanotechnology is an emerging strategy designed to eliminate the awful effects of food shortage, heavy metal contamination, and other abiotic stresses. Iron oxide nanoparticles play a proficient role in increasing the growth, development, and enhancement of the stress tolerance of plants and the provision of nutrients [21].

Considering the potential of region for future agricultural developments, we propose to launch a pilot project of remediation of contaminated soils based on technologies applying nanoscale zerovalent iron particles and biochar composites.

\section{REFERENCES}

1. Alsaab, D., Elie, M., Izart, A., Sachsenhofer, R.F. and Privalov, V.A. (2008), AAPG Bulletin, Vol. 92, No. 8, pp. $1029-1053$. https://doi.org/10.1306/03250807053

2. Alsaab, D., Elie, M., Izart, A., Sachsenhofer, R.F., Privalov, V.A., Suarez-Ruiz, D., Martinez, L. (2008), Int. J. Coal Geology, Vol. 74(2), pp. 154-162. https://doi.org/10.1016/j.coal.2007.11.006

3. Alsaab, D., Elie, M., Izart, A., Sachsenhofer, R.F., Privalov, V.A., Suarez-Ruiz, D. and Panova, E.A. (2009), Int. J. Coal Geology, Vol. 78(1), pp. 27-37. https://doi.org/10.1016/j.coal.2008.09.004

4. Danisik, M., Sachsenhofer, R.F., Frisch, W., Privalov, V.A., Panova, E.A. and Spiegel, C. (2010), Basin Research, Vol. 22, pp. 681-698. https://doi.org/10.1111/j.1365-2117.2009.00434.x

5. De Boorder, H., Zeylmans van Emmichoven, M.J. and Privalov, V.A. (2006), Ore Geol. Rev., Vol. 29, No. 3-4, pp. $242-259$. https://doi.org/10.1016/j.oregeorev.2005.10.001

6. Izart, A., Sachsenhofer, R.F., Privalov, V.A., Elie, M., Panova, E., Antsiferov, A., Alsaab, D., Rainer, T., Sotirov, A., Zdravkov, A. and Zhykalyak, M.V. (2006), Int. J. Coal Geology, Vol. 66, No. 1-2, pp. 69-107. https://doi.org/10.1016/j. coal.2005.07.002

7. Kolker, A., Panov, B., Panov, Y., Landa, E., Conko, K., Korchemagin, A., Shendrik, T. and McCord, J. (2009), Int. J. Coal Geology. Vol. 79 (3), pp. 83-91. https://doi.org/10.1016/j.coal.2009.06.003

8. Mitzia, A., Vítková, M. and Komárek, M. (2020), Chemosphere, Vol. 242, p. 125248. https://doi.org/10.1016/j. chemosphere.2019.125248

9. Panova, O.A., Pryvalov, V.A., Izart, A., Alsaab, D. and Antsiferov, V.A. (2009), Proc. of the 71st EAGE Conf. \& Exhibition incorporating SPE EUROPEC 2009, Amsterdam, 2009. https://doi.org/10.3997/2214-4609.201400154

10. Panova, O.A., Pryvalov, V.A., Sachsenhofer, R.F. and Antsiferov, V.A. (2011), 73rd EAGE Conf. \& Exhibition incorporating SPE EUROPEC 2011, Vienna, 2011. https://doi.org/10.3997/2214-4609.20149494

11. Privalov, V.A. and Panova, E.A. (2008), 3rd EAGE Int. Conf. and Exhibition on Geosciences - Geosciences: From New Ideas to New Discoveries, Saint Petersburg, 2008. https://doi.org/10.3997/2214-4609.20146858

12. Privalov, V.A., Sachsenhofer, R.F., Panova, O.A. and Izart, A. (2011), Geologist of Ukraine, Vol. 2 (6), pp. 152-157.

13. Privalov, V., Randi, A., Sterpenich, J., Pironon, J. and Morlot, C. (2019), Geosciences, 2019, Vol. 9(1), p. 33. https:// doi.org/10.3390/geosciences9010033

14. Pryvalov, V.A., Izat, A., Alsaab, D., Sachsenhofer, R., Panova, O.A. and Antsiferov, V. (2009), 71st EAGE Conf. and Exhibition incorporating SPE EUROPEC 2009, Amsterdam 2009. https://doi.org/10.3997/2214-4609.201400024

15. Pryvalov, V.A., Panova, O.A., Sachsenhofer, R.F., Izart, A. (2011), 73rd EAGE Conference \& Exhibition incorporating SPE EUROPEC 2011, Vienna, 2011. https://doi.org/10.3997/2214-4609.20149496

16. Pryvalov, V.A., Panova, O.A. and Sachsenhofer, R.F. (2013), 75th European Association of Geoscientists and Engineers Conference and Exhibition Incorporating SPE EUROPEC 2013, London, 2013, pp. 3607-3612. https://doi. org/10.3997/2214-4609.20130809 
17. Sachsenhofer, R.F., Privalov, V.A., Izart, A., Elie, M., Kortensky, J., Panova, E.A., Sotirov, A. and Zhykalyak, M.V. (2003), Int. J. Coal Geology, Vol. 55, No. 2, pp. 225-259. https://doi.org/10.1016/S0166-5162(03)00112-5

18. Sachsenhofer, R.F., Privalov, V.A. and Panova, O.A. (2012), Int. J. Coal Geology, Vol. 89(1), pp. 26-40. https://doi. org/0.1016/j.coal.2005.07.0021

19. Saintot, A., Stephenson, R., Brem, A., Stovba, S. and Privalov, V. (2003), Tectonics, Vol. 22, No. 5, p. 1059. https://doi. org/10.1029/2002TC001366

20. Vervoort, A. and Declercq, P.Y. (2018), Int. J. Min. Sci. Technol., Vol. 28(1), pp. 53-59. https://doi.org/10.1016/j. ijmst.2017.11.008

21. Vítková, M., Rákosová, S., Michálková, Z. and Komárek, M. (2017), J. Environmental Management, Vol. 186 (2), pp. 268-276. https://doi.org/10.1016/j.jenvman.2016.06.003

Received 13.01.2020

B.O. Привалов, д-р геол. наук, проф., пров. наук. співроб. Інститут геохімії, мінералогії та рудоутворення ім. М.П. Семененка НАН України

03142, Київ, Україна, пр-т Акад. Палладіна, 34

E-mail: vitaliy.privalov@gmail.com

http://orcid.org/0000-0002-1429-6960

O.A. Панова, канд. геол.-мін. наук, пров. наук. співроб. Інститут геохімії,

мінералогії та рудоутворення ім. М.П. Семененка НАН України

03142, Київ, Україна, пр-т Акад. Палладіна, 34

E-mail: olena.panova@gmail.com

http://orcid.org/0000-0002-3813-5125

A.B. Привалов, бакалавр (довкілля і науки про Землю), магістрант

Чеський університет наук про життя

Kamýcká 129, 16500 Praha-Suchdol, Чexiя

E-mail: andriy.privalov@gmail.com

https://orcid.org/0000-0002-3045-7111

\section{ГЕОЛОГІЯ В ПРОБЛЕМАХ ПРИРОДОКОРИСТУВАННЯ ДОНБАСУ В КОНТЕКСТІ ЙОГО МАЙБУТНЬОГО ВІДНОВЛЕННЯ}

Донецький басейн (Донбас) - це один із найбільших пізньопалеозойських вугільних басейнів світу. У геологічному сенсі цей басейн виділяється потужним осадовим чохлом, котрий містить багаті на вугілля поклади. На теренах Донецької складчастої споруди цей басейн зазнав інверсійно-складчастих рухів, керованих принциповою дислокаційною зоною (ПДЗ). Тривалий час Донбас виконував роль найважливішого осередку української промисловості, видобутку вугілля та ртуті, численні металургійні та хімічні підприємства, переробні майданчики. У басейні ідентифікована велетенська маса органічної речовини, достатній ступінь його термального дозрівання дають змогу розглядати Донбас як найбільше родовище вуглеводнів із нетрадиційними колекторами, включаючи значні поклади "сланцевого газу" та вугільного метану, котрі можуть забезпечити ресурсну базу для припинення української залежності від імпорту газу з РФ. Зараз цей геологічний та економіко-географічний регіон потерпає від тривалих бойових дій, наслідки яких у екологічному сенсі є непередбачуваними та загрожують безпеці сусідніх територій. Метою цієї публікації є дослідження загрози убивчої комбінації історично стійких техногенних змін і збройного конфлікту, що вплинули на повітряно-наземне та підземне середовище, міські об'єкти та інфраструктурні споруди, грунти та розвиток сільського господарства в межах Донбасу (Східна Україна). Дослідження виконано на підставі аналізу даних довго- та короткотермінових спостережень навколишнього середовища, зібраних у Донецькому басейні з метою типізації й визначення найактуальніших екологічних проблем сьогодення, а також формулювання наріжних завдань для його майбутнього відновлення. Особливу увагу приділено розвитку екологічних проблем з 2014 року дотепер, зокрема окреслено ризики, пов'язані з конкретним геоструктурним положенням ділянки підземного ядерного вибуху "Кліваж" та індукованою сейсмічною активністю, що мала місце поблизу селища Об’єднаний (Ханжонково, м. Макіївка) у 2019 році. Описано методи виявлення та профілактики проблем геологічного та навколишнього середовища. Обговорено коригувальні заходи, які можуть бути вжиті.

Ключові слова: Донбас, геонебезпечні ділянки, збройний конфлікт, впливи на навколишнє середовище, ділянка підземного ядерного вибуху "Кліваж", індукована сейсмічність, забруднення земель.

Надійшла 13.01.2020 